\title{
VZDĚLÁVACÍ POLITIKA A MEZINÁRODNÍ VÝZKUMY VÝSLEDKŮ VZDĚLÁVÁNÍ V ČR
}

\author{
JANA STRAKOVÁ
}

\begin{abstract}
Anotace: $V$ průběhu uplynulých 15 let se uskutečnila $v$ České republice rada mezinárodních výzkumů, jejichž cílem bylo porovnat vědomosti a dovednosti českých žáků $s$ vědomostmi a dovednostmi jejich vrstevníků v zahraničí. Výzkumy byly zaměřeny na různé oblasti vzdělávání a na různé věkové kategorie žáků a poskytly řadu cenných informací o českém vzdělávacím systému. Cílem tohoto textu je poskytnout prehled uskutečněných výzkumů, seznámit čtenáře s jejich souhrnnými zjištěními a diskutovat dopad výzkumů a jejich zjištění na vzdělávací politiku v ČR.
\end{abstract}

Klíčová slova: Mezinárodní srovnávací výzkumy, OECD PISA, IEA, výsledky vzdělávání, vzdèlávací politika

Abstract: In last fifteen years the Czech Republic participated in many international comparative studies of student achievement. These studies provided comparisons of knowledge and skills of Czech students with knowledge and skills of their peers in other countries. Surveys focused on various educational areas and on various age cohorts and brought valuable information about Czech education system. The aim of this paper is to provide overview of international comparative studies on student achievement implemented in the Czech Republic and related national surveys, to present main findings and to discuss their impact on Czech educational policy.

Key words: International comparative studies, OECD PISA, IEA, student achievement, educational policy

\section{MEZINÁRODNÍ VÝZKUMY V OBLASTI VZDĚLÁVÁNÍ A JEJICH REALIZACE V ČESKÉ REPUBLICE}

\subsection{VÝZKUMY MEZINÁRODNÍ ASOCIACE PRO HODNOCENÍ VÝSLEDKU゚ VZDĚLÁVÁNÍ}

Organizátorem většiny mezinárodních srovnávacích výzkumů v oblasti vzdělávání ve druhé polovině 20. století byla Mezinárodní asociace pro hodnocení výsledků vzdělávání'. Česká republika se do mezinárodních aktivit na poli hodnocení

1 Mezinárodní asociace pro hodnocení výsledků vzdělávání (International Association for the Evaluation of Educational Achievement - IEA) byla založena v roce 1959 jako sdružení několika výzkumných institucí z celého světa. Mezi její zakladatele patřil např́ílad Benjamin Bloom, tvůrce známé taxonomie vzdělávacích cílů. Od doby svého vzniku uskutečnila asociace zhruba 30 výzku- 
výsledků vzdělávání zapojila až na počátku 90. let minulého století, kdy se spolu $s$ většinou ostatních postkomunistických zemí stala členem této organizace. ${ }^{2}$ Do té doby nebyly v České republice $\mathrm{k}$ dispozici žádné objektivní informace o výsledcích vzdělávacího systému jako celku, hodnocení systému bylo zpravidla založeno na informacích o výsledcích jednotlivců $v$ mezinárodních soutěžích. $V$ rámci socialistického bloku se komparace neprováděly, monitorování výsledků vzdělávání nebylo běžné ani na národní úrovni.

Na přelomu 20. a 21. století se Česká republika zúčastnila všech šetření IEA, která v té době probíhala. První mezinárodní šetření se na českých školách uskutečnila $v$ roce 1995, kdy byl na základních školách proveden výzkum čtenářské gramotnosti ${ }^{3}$ a na základních a středních školách výzkum matematického a prírodovědného vzdělávání. ${ }^{4}$ Výzkum čtenářské gramotnosti byl v modifikované podobě zopakován v roce $2001^{5}$, výzkum matematického a prírodovědného vzdělávání v roce 1999 a v roce $2007 .{ }^{\circ} \mathrm{V}$ roce 1999 byl dále proveden výzkum občanské výcho-

mů v různých oblastech vzdělávání. Výzkumy byly postupně zdokonalovány, v souvislosti s moderními poznatky se zlepšovaly metody výběru vzorku, vývoje testů, zjištování kontextuálních informací, zpracování dat. Spolu s tím se zvětšovala i rozmanitost výstupů vzdělávání, které byly zjištovány. Zároveň rostl i počet zemí, které se do práce asociace zapojily. První studie v letech 1959 - 1962 se zúčastnilo 12 zemí, v současné době má asociace 68 členských zemí z celého světa. $\checkmark$ průběhu celé své činnosti IEA realizovala opakovaně šetřeni v oblasti matematiky, prírodovědných předmětů a čtenářské gramostnosti. Na přelomu 20. a 21. století nabyla tato šetření podoby pravidelného promyšleného cyklu. Výzkum Trends in Mathematics and Science Study, který navazuje na Third International Mathematics and Science Study uskutečněný v letech 1995 a 1999, byl realizován v roce 2003 a 2007. Další šetření je plánováno na rok 2011. V roce 2001 se rozběhl rovněž cyklus šetření ve čtenářské gramotnosti Progress in Reading Literacy Study. Další šetření je plánováno rovněž na rok 2011. Opakovaně je realizován rovněž výzkum občanské výchovy (1999, 2009). Kromě těchto dvou výzkumů je v současné době ve fázi realizace ještě výzkum informačních technologií Second Information on Technology in Education Study, výzkum občanské výchovy International Civic and Citizenship Education Study a výzkum zaměřený na učitele Teacher Education and Development Study. Organizace má kancelář v Amsterodamu. Informace jsou dostupné na http://www.iea.nl

2 Výjimku v tomto ohledu tvořily Mad'arsko a Polsko, které se do mezinárodních výzkumných aktivit zapojily dříve. Mad’arsko bylo dokonce zakládajícím členem IEA.

3 IEA RLS (Reading Literacy Study). V členských zemích IEA proběhl výzkum v roce 1991, ČR jej realizovala v roce 1995. Testovaní žáci: 3. a 8. ročník ZŠ. Výzkumné nástroje: žákovský test, žákovský dotazník, učitelský dotazník, školní dotazník (pro ředitele školy). Výzkum proběhl v 33 zemích, v ČR se ho zúčastnilo 130 škol, 5520 žáků (Straková 1995).

4 IEA TIMSS (Third International Mathematics and Science Study). Testovaní žáci: 3. a 4. ročník ZŠ, 7. a 8. ročník ZŠ, poslední ročník všech typů SŠ. Výzkumné nástroje: žákovský test, žákovský dotazník, učitelský dotazník, školní dotazník (na SŠ proběhla administrace bez učitelských dotazníků). Výzkum proběhl v 43 zemích, v ČR se ho zúčastnilo 500 škol, 16700 žáků (Straková, Tomášek 1996; Straková, Palečková, Tomášek 1997; Straková, Tomášek, Palečková 1998).

5 IEA PIRLS (The Progress in International Reading Literacy Study). Testovaní žáci: 4. ročník ZŠ. Výzkumné nástroje: žákovský test, žákovský dotazník, rodičovský dotazník, učitelský dotazník, školní dotazník. Výzkum proběhl v 35 zemích, v ČR se ho zúčastnilo 141 škol, 3030 žáků (Kramplová, Potužníková 2005).

6 IEA TIMSS-R (Third International Mathematics and Science Study - Repeat). Testovaní žáci: 8. ročník ZŠ. Výzkumné nástroje: žákovský test, žákovský dotazník, učitelský dotazník, školní dotazník. Výzkum proběhl v 38 zemích, v ČR se zúčastnilo 150 škol, 3600 žáků (Palečková, Tomášek 2001). IEA 
vy, který byl zaměřen na žáky 2. stupně ZŠ a na žáky středních škol ${ }^{7}$, na jaře roku 2009 proběhl výzkum občanské výchovy ICCS - International Civic and Citizenship Education Study v 8. ročnících ${ }^{8}$. ČR se nezúčastnila výzkumu čtenářské gramotnosti $v$ roce 2006 a matematického a prírodovědného vzdělání v roce 2003. Nejbližšími plánovanými výzkumy je výzkum matematické a př́rodovědné gramotnosti (TIMSS) a čtenářské gramotnosti (PIRLS) v roce 2011.

Výzkumy IEA obsahují testy tvořené z velké části úlohami, ve kterých žáci vybírají z několika nabízených odpovědí jedinou správnou. Dále jsou zastoupeny úlohy, ve kterých žáci odpovídají jednoslovně či několika slovy a kde poskytují obsáhlejší odpověd' nebo úplné řešení dané úlohy. Obsahová náplň testu je volena jako průnik učiva všech zúčastněných zemí pro danou oblast vzdělávání a př́slušnou věkovou skupinu. Testy jsou nicméně konstruovány tak, aby úlohy pokryly i jiné než obsahové aspekty výstupů vzdělávání. $V$ testu matematického a př́rodovědného vzdělávání jsou úlohy klasifikovány podle vzdělávacího obsahu a myšlenkových dovedností (prokazování znalostí, použivání znalostí, uvažování). V testech čtenářské gramotnosti jsou klasifikovány podle typu čtenářské činnosti: získávání informací, vyvozování, interpretace a hodnocení. Do výzkumu matematického a prírodovědného vzdělávání v roce 1995 byly zahrnuty úlohy, které zjištovaly experimentální dovednosti žáků, v ČR tyto úlohy řešili žáci 8. ročníků. Úlohy ve výzkumu občanské výchovy jsou koncipovány tak, aby postihovaly vědomosti, dovednosti i postoje testovaných. Dủležitou součástí výzkumů jsou dotazníky pro žáky, učitele, ředitele škol a prípadně rodiče žákủ. Zjištují doplňující informace týkající se žáků (mimoškolní činnost, domácí zázemí, plány do budoucna) a výuky v dané oblasti vzdělávání (jak ji vnímá žák, učitel, ředitel, rodič). Výběr vzorku probíhal ve všech prípadech dvoustupňově: nejprve je náhodně vybrán určitý počet škol z databáze všech škol, které jsou navštěvovány žáky v dané věkové kategorii, v rámci těchto škol pak je náhodně vybrána jedna třída v príslušném ročníku.

\subsection{VÝZKUM OECD PISA}

V průběhu 90. let se Česká republika zapojila rovněž do komparativních aktivit, které na poli vzdělávání realizovala Organizace pro hospodářskou spolupráci a rozvoj (OECD). Čeští odborníci začali pracovat v technické skupině projektu INES a dalších pracovních týmech, jejichž úkolem je shromažd’ovat datové podklady pro statistické ukazatele do každoročně vydávané publikace Education at a Glance

TIMSS (Trends in Mathematics and Science Study). Testovaní žáci: 4. ročník ZŠ, 8. ročník. Výzkumné nástroje: žákovský test, žákovský dotazník, učitelský dotazník, školní dotazník. Výzkum proběhl v 59 zemích, v ČR se zúčastnilo 291 škol, 291 ředitelů, 1009 učitelů, 4235 žáků 4. ročníků, 4845 žáků 8. ročníků (Tomášek et al. 2008).

7 IEA CivEd (Civic Education Study). Testovaní žáci: 8. ročník ZŠ, 3. ročník SŠ. Výzkumné nástroje: žákovský test, žákovský dotazník, učitelský dotazník, školní dotazník. Výzkum proběhl v 28 zemích, v ČR se zúčastnilo 300 škol, 6900 žáků (Křížová 2000; Procházková, Raabová 2002).

8 V době vzniku tohoto textu data nebyla ještě zpracována. 
(EaG). Ukazatele charakterizující výsledky vzdělávání byly do EaG zprvu přejímány $z$ výše uvedených výzkumů asociace IEA. Koncem 90 . let však OECD navrhla vlastní výzkumný projekt PISA, ${ }^{9}$ do kterého se Česká republika rovněž zapojila.

Projekt je koncipován jako cyklus šetření v oblasti matematické, prírodovědné a čtenářské gramotnosti, která jsou zaměřena na patnáctileté žáky a probíhají v tříletých intervalech. Dosud byla realizována tři šetření - v letech 2000, 2003 a 2006. $\checkmark$ každém cyklu byl kladen důraz na jednu z hodnocených oblastí. $V$ roce 2000 byla stěžejní čtenářská gramotnost, v roce 2003 matematika, v roce 2006 prírodovědná gramotnost. $V$ roce 2000 byly navíc zjištovány metakognitivní dovednosti žáků, $v$ roce 2003 dovednosti při řešení problémových úloh a v roce 2006 postoje žáků k prírodním vědám a k životnímu prostředí.

I ve výzkumech PISA probíhá výběr vzorku dvoustupňově, ve školách však není vybírána třída ze stanoveného ročníku, ale žáci narození ve zvoleném kalendářním roce. ${ }^{10}$ Tento způsob výběru je pro ČR nevýhodný. Skutečnost, že se polovina žáků nachází v povinném vzdělávání a polovina na střední škole činí interpretaci některých zjištění ve vztahu k českému vzdělávacímu systému poněkud problematickou.

Testy výzkumu PISA jsou na první pohled podobné testům z výzkumů IEA. Odlišnost spočívá v tom, že ve výzkumu PISA jsou více zastoupeny úlohy, ve kterých žáci odpovídají vlastními slovy. Úlohy jsou uvozeny nějakým autentickým textem, grafem nebo obrázkem, za kterým následuje sada otázek. Žáci tak pracují delší dobu $s$ jedním tématem a mohou se tak na ně plně soustředit. $Z$ hlediska měření je však tento př́stup nevýhodný v tom, že na sobě jednotlivé úlohy nejsou úplně nezávislé. Obsah testu není určován probíraným učivem, ale předem vypracovanými rámcovými koncepcemi, na jejichž tvorbě se podílejí přední světoví odborníci na jednotlivé testované oblasti ${ }^{11}$, koncepce oblastí se průběžně inovují spolu s tím, jak se vyvijí stav poznání a pohled na jednotlivé sledované oblasti. Přitom je kladen větší důraz na provázanost vědomostí a dovedností se situacemi, s nimiž se lze se-

9 V roce 2000 byli do výzkumu zařazeni žáci narození v roce 1984, v roce 2003 žáci narození v roce 1987, v roce 2006 žáci narození v roce 1990. Výběr byl prováděn ze všech žáků s daným rokem narození, kteří navštěvovali danou školu bez ohledu na ročník, ve kterém se nacházeli. Výzkumu se tak s žáky 9. ročníků ZŠ a 1. ročníků SŠ zúčastnilo i několik žáků 7. a 8. ročníků. V roce 2000 byly výzkumné nástroje v České republice rovněž administrovány žákům narozeným v roce 1982 navštěvujícím 3. ročníky zúčastněných středních škol (3100 žáků).

10 OECD PISA (Programme for International Student Assessment). Testovaní žáci: žáci, kteř́ v kalendářním roce testování dosáhnou 16 let. Výzkumné nástroje: žákovský test, žákovský dotazník, školní dotazník. V roce 2000 proběhl výzkum ve 32 zemích, v ČR se zúčastnilo 253 škol, 6300 žáků. V roce 2003 proběhl výzkum ve 41 zemích, v ČR se zúčastnilo 260 škol, 9920 žáků. V roce 2006 výzkum proběhl v 57 zemích, v ČR se ho zúčastnilo 245 škol, 8890 žáků (OECD 2001, 2004, 2007).

11 Př́prava výzkumu PISA byla zahájena na počátku 90. let v Networku A projektu INES. Bylo přijato rozhodnutí, že výzkum nebude testovat kurikulární obsahy, ale zaměří se na kompetence „důležité pro život". Tyto kompetence však nebyly nikterak konceptualizovány. Realizaci výzkumu PISA proto předcházel projekt DeSeCo (Defining and Selecting Competencies), jehož cílem bylo tyto klíčové kompetence definovat. Vymezení kompetencí vzniklo jako syntéza pohledů předních světových odborníků z různých oborů lidského konání, kteří byli v rámci projektu osloveni. Projekt ukázal, že pohledy jednotlivých odborníků jsou natolik různorodé, že nebylo možno je pro měření PISA bezprostředně využít. Vznikl však pozoruhodný soubor zamyšlení nad cíli a úlohou vzdělávání v moderní společnosti (Rychen, Salganik 2001). 
tkat $v$ běžném životě, koncepce zohledňují zejména důležitost dílčích vědomostí a dovedností pro úspěšné fungování $v$ životě osobním, společenském a na trhu práce. V roce 2009 například bylo zařazeno do výzkumu PISA čtení elektronických textů, nebot' se stává autentickou součástí každodenního života a vyžaduje poněkud jiné dovednosti než četba tišš̌ných textů ${ }^{12}$. Součástí výzkumu PISA jsou pouze dotazníky pro ředitele a žáky, dotazníky pro učitele chybějí, oblast výuky je mapována méně podrobně než v šetřeních IEA. To souvisí i se způsobem výběru vzorku: zatímco ve výzkumech IEA je testována vždy celá třída a je tedy možno dotazovat učitele, kteří ji vyučují, ve výzkumu PISA jsou vybíráni náhodně žáci z různých tříd. Výzkum PISA však zjištujuje daleko důkladněji než výzkumy IEA rodinné zázemí žáků (žáci jsou dotazováni nejen na vzdělání, ale rovněž na zaměstnání rodičů, majetkové a kulturní vybavení domácností).

Zatímco výzkumy IEA byly vždy koncipovány výzkumníky a sloužily primárně pedagogickému výzkumu ${ }^{13}$, výzkum PISA si klade za cíl ovlivňovat vzdělávací politiku v jednotlivých zemích. O cílech šetření rozhodují zástupci ministerstev školství prostřednictvím řídícího výboru, výstupy jsou koncipovány tak, aby z nich čerpali primárně tvůrci školské politiky. Podle původního záměru byl cyklus šetření PISA určen pouze pro členské země OECD. Mezi nečlenskými zeměmi byl však o výzkum takový zájem, že došlo k jeho zpřístupnění všem vzdělávacím systémům, které jsou schopny ho realizovat $v$ požadované technické kvalitě. Obsah výzkumu je však koncipován tak, aby z něj profitovaly primárně země OECD.

Zjištěním výzkumu PISA je obecně přikládána mezi tvůrci vzdělávacích politik velká vážnost. V řadě systémů jsou výkyvy ve výsledcích žáků popudem pro okamžité kroky vzdělávací politiky. Přestože má výzkum PISA i své metodologické kritiky z řad akademiků, jsou jeho data používána výzkumníky na celém světě a je na nich založena řada zajímavých analýz ${ }^{14}$. Velkou zásluhou výzkumu PISA je rozpracování konceptů matematické, prírodovědné a čtenářské gramotnosti do struktury použitelné k mezinárodním měřením a obrácení pozornosti tvůrců vzdělávacích politik od "kurikulárních vědomosti” ke „kompetencím pro život". V tomto smyslu se výzkum PISA stal pro řadu zemí (a pravděpodobně i pro Českou republiku) impulsem pro reformy $v$ oblasti kurikul. Některé systémy dokonce hledaly společenský konsensus identicky jako zmiňovaný projekt DeSeCo, tedy dotazovaly odborníky z rozmanitých profesí a klíčové kompetence definovaly jako průnik jejich preferencí (Eurydice 2002).

12 ČR se elektronického testování nezúčastnila.

13 Již bylo zjištěno, že výzkumy IEA se v daleko větší míre než výzkumy OECD zaměřují na mapování výuky. Kromě podrobných učitelských dotazníků byla jejich součástí rovnež mnohá doplňková šetření. Například v roce 1995 a 1999 byly ve vybraních zemích nahrávány a podrobně analyzovány vyučovací hodiny matematiky a prírodovědných předmětů. ČR se tohoto výzkumu (TIMSS 1999 Videostudy) zúčastnila v roce 1999, do mezinárodního srovnání bylo zahrnuto 100 českých vyučovacích hodin matematiky a 100 hodin prírodovědných předmětů (Hiebert 2003; Roth 2006).

$14 \mathrm{~K}$ rostoucímu využití dat přispěla jistě i skutečnost, že organizátoři studií začali zveřejňovat spolu $s$ daty pomocné programy, které umožňují jednoduše a správně s daty pracovat, tedy správně používat odhady žákovských výsledků (plausible values) a replikační váhy sloužící k řádnému odhadu standardní chyby výsledku. Dokud nebyla k dispozici tato pomoc, řadu výzkumníků odradila komplikovanost dat a náročnost výpočtů. 
Hlavní zásluha výzkumu PISA však spočivá bezpochyby v tom, že obrátil pozornost odborné veřejnosti k problematice vzdělanostních nerovností na úrovni povinného vzdělávání. Podrobné mapování rodinného zázemí umožňuje analytikům pravidelně informovat o míre rozdílů mezi žáky a školami v jednotlivých systémech a o síle vazby mezi výsledky vzdělávání a rodinném zázemí. Důraz, který OECD klade na tento typ indikátorů, významně přispěl k tomu, že se otázkou nerovností na úrovni povinného vzdělávání začaly zabývat i systémy, které jí dosud nevěnovaly pozornost, a že se otázka spravedlivosti (equity) ocitla na prvním místě v žebříčku politických priorit v mnoha vyspělých zemích.

$\checkmark$ následující kapitole popíšeme hlavní poznatky mezinárodních výzkumů vědomostí a dovedností $v$ ČR, v poslední kapitole se zamyslíme nad dopady těchto výzkumů na vzdělávací politiku.

\section{VÝSLEDKY ČESKÝCH ŽÁKŮ V MEZINÁRODNÍM SROVNÁNÍ}

\subsection{VĚDOMOSTI A DOVEDNOSTI}

\section{Pohled na celkové výsledky a jejich vývoj}

Ve všech citovaných výzkumech bylo posuzování úspěšnosti jednotlivých vzdělávacích systémů založeno na komparaci s ostatními zúčastněnými zeměmi, složení zemí se však v různých výzkumech lišilo, do výzkumů IEA i do výzkumu PISA se rostoucí měrou zapojují rozvojové země z celého světa. Lišily se i cílové populace žáků a koncepce výzkumů, ačkoli byly mnohé z nich zaměřeny na stejné oblasti vzdělávání. Z těchto důvodů není možno výsledky jednotlivých výzkumů přímo porovnávat a s jejich využitím podrobněji monitorovat vývoj v jednotlivých vzdělávacích oblastech. Odhlédneme-li však od specifik jednotlivých výzkumů a drobných výkyvů ve výsledcích českých žáků, ${ }^{15}$ získáme dosti stabilní obrázek o výsledcích českého vzdělávacího systému, jeho silných a slabých stránkách.

Čeští žáci na konci povinné školní docházky dosahují opakovaně nadprůměrných výsledků v přirodovědných předmětech, průměrných výsledků v matematice a podprůměrných výsledků v testech zjištujících úroveň čtenářské gramotnosti (ÚIV 2002). Tato obecná tendence se potvrdila i v zatím posledních provedených výzkumech PISA 2006 (OECD 2007) a TIMSS 2007 (Tomášek et al. 2008). Vývoj umístění ČR v žebríičcích zemí OECD pro 8. ročník, resp. populaci patnáctiletých uvádíme v Tabulce 1.

15 Výkyvy mají pravděpodobně řadu různých př́ǐcin. Například horší výsledek českých žáků ve výzkumu TIMSS v roce 1999 ve srovnání s výzkumem TIMSS v roce 1995 můžeme vysvětlit tím, že v roce 1996 přešla ČR na devítiletou základní školu. Žáci 8. ročníku, na které byl výzkum zaměřen, byli v roce 1995 ve stádiu přípravy k přijímacím zkouškám a byli tedy připraveni podávat maximální výkony. V této době měli žáci také probráno veškeré učivo základní školy. V roce 1999 již tomu tak nebylo. Podobný efekt byl pozorován i v jiných zemích s podobným systémem (např. v Mad'arsku). Rozdíly ve výsledcích žáků mohou být zpưsobeny i různým obsahem testů (důraz na jiné učivo). Na základě těchto poznatků doporučujeme pojímat informaci o umístění českých žáků v mezinárodních žebříčcích sestavených na základě dílčích výzkumů pouze jako informaci rámcovou. 
Tab. 1: Výsledky českých žáků na konci povinné školní docházky v mezinárod-

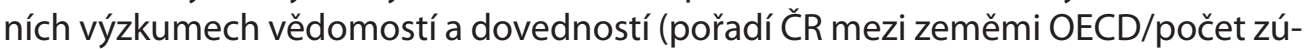
častněných zemí OECD)

\begin{tabular}{|l|c|c|c|c|c|c|}
\hline & TIMSS & TIMSS & PISA & PISA & PISA & TIMSS \\
& $\mathbf{1 9 9 5}$ & $\mathbf{1 9 9 9}$ & $\mathbf{2 0 0 0}$ & $\mathbf{2 0 0 3}$ & $\mathbf{2 0 0 6}$ & $\mathbf{2 0 0 7}$ \\
\hline matematika & $3 / 24$ & $10 / 15$ & $17 / 27$ & $10 / 29$ & $11 / 30$ & $8 / 15$ \\
př́rodní vědy & $1 / 24$ & $6 / 15$ & $11 / 27$ & $6 / 29$ & $10 / 30$ & $5 / 15$ \\
& & $\begin{array}{c}\text { RLS } 1995 \\
13 / 20\end{array}$ & $19 / 27$ & $20 / 29$ & $20 / 29$ & \\
čtenářská gramotnost & & $19 / 20$ & \\
\hline
\end{tabular}

Zdroj: TIMSS, PISA, RLS

Silné a slabé stránky českého vzdělávacího systému v jednotlivých oblastech vzdělávání jsou konsistentní přes oba stupně základní školy a potvrzují je rovněž výsledky výzkumu gramotnosti dospělých SIALS, který se v České republice uskutečnil v roce $1998 .{ }^{16}$ Česká dospělá populace $v$ něm dosáhla výborných výsledků v oblasti kvantitativní gramotnosti, která souvisí právě s matematickými dovednostmi. Velmi dobrých výsledků dosáhli Češi i v oblasti dokumentové gramotnosti, což odpovídá zjištění o dobrých výsledcích školáků při práci s nesouvislými texty (grafy, tabulky apod.), které prokázaly všechny výzkumy čtenářské gramotnosti $v$ žákovské populaci. Podprůměrné výsledky měli čeští dospělí občané naopak v oblasti literární gramotnosti, která do značné míry odpovídá dovednosti pracovat se souvislými texty zjištované ve výzkumech školáků.

Výzkum TIMSS i výzkum PISA jsou koncipovány tak, že umožňují srovnávat výsledky žáků $v$ jednotlivých letech a mapovat tak jejich vývoj v čase. Zatímco výsledky výzkumu PISA neprokázaly statisticky významné zhoršení ani v jedné ze sledovaných oblastí, ve výsledcích matematického testu TIMSS došlo mezi roky 1999 a 2007 ke statisticky významnému zhoršení u žáků 8. ročníků. Podrobnější pohled na výsledky žáků jednotlivých typů studia nicméně ukazuje, že jak v testech PISA, tak v testech TIMSS došlo ke statisticky významnému zhoršení u žáků základních škol, přičemž výsledky žáků víceletých gymnázií jsou stabilní (Tabulky 2 a 3).

16 Výzkum SIALS (Second International Adult Literacy Survey) se uskutečnil pod vedením Statistics Canada ve druhé polovině 90 . let 20 . století ve 20 zemích. Zkoumal úroveň literární, dokumentové a kvantitativní gramotnosti populace ve věku 15-65 let (OECD 2000). Další výzkum v této populaci je plánován na rok 2011 (Programme for International Assessment of Adult Competencies). 
Tab. 2: Výsledky žáků základních škol a víceletých gymnázií v testu čtenářské gramotnosti PISA (tučné výsledky se v jednotlivých letech statisticky významně liší)

\begin{tabular}{lcccc}
\hline & \multicolumn{2}{c}{2000} & \multicolumn{2}{c}{2006} \\
& výsledek & $($ se $)$ & výsledek & $($ se $)$ \\
\hline ZŠ & $\mathbf{4 7 5}$ & $\mathbf{( 3 , 3 )}$ & $\mathbf{4 6 4}$ & $\mathbf{( 3 , 5 )}$ \\
ZŠ s rozšířenou výukou & 500 & $(10,3)$ & 506 & $(12,7)$ \\
víceleté gymnázium & 579 & $(7,1)$ & 602 & $(3,7)$ \\
ČR průměr & $\mathbf{4 9 1 , 6}$ & $\mathbf{( 2 , 4 )}$ & $\mathbf{4 8 2 , 7}$ & $\mathbf{( 4 , 2 )}$ \\
\hline
\end{tabular}

Zdroj: PISA 2000, 2006

Tab. 3: Výsledky žáků základních škol a víceletých gymnázií v matematickém testu TIMSS (tučné výsledky se v jednotlivých letech statisticky významně liší)

\begin{tabular}{lcccc}
\hline & \multicolumn{2}{c}{1999} & \multicolumn{2}{c}{2007} \\
& výsledek & $($ se) & výsledek & $($ se) \\
\hline ZŠ & $\mathbf{5 1 1}$ & $\mathbf{( 0 , 6 )}$ & $\mathbf{4 9 3}$ & $\mathbf{( 0 , 4 )}$ \\
víceleté gymnázium & 615 & $(1,4)$ & 608 & $(3,3)$ \\
celkem & $\mathbf{5 2 0}$ & $\mathbf{( 0 , 5 )}$ & $\mathbf{4 7 4}$ & $\mathbf{( 3 , 7 )}$ \\
\hline
\end{tabular}

Zdroj: TIMSS 1999, 2007

Velkou pozornost vzbudilo zhoršení ve výsledcích žáků 4. ročníků ZŠ v matematice ve výzkumu TIMSS mezi lety 1995 a 2007, které bylo nejvyšší mezi 14 zeměmi OECD, které se zúčastnily výzkumu v obou sledovaných obdobích. Až budoucnost (např́klad srovnání vědomostí žáků 8. ročníků ve výzkumu TIMSS v roce 2011) ukáže, do jaké míry je tento nález způsoben prodloužením školní docházky a změnou $\checkmark$ rozložení učiva (viz. pozn. 13) a bude tedy v průběhu školní docházky kompenzován a do jaké míry vypovídá o skutečném zhoršování vědomostí a dovedností žáků. 


\section{Výsledky v dílčích oblastech}

Testy čtenářské gramotnosti zjištovaly, do jaké míry jsou žáci schopni vyhledávat informace $v$ různých typech textů, interpretovat přečtený text a zaujmout $\mathrm{k}$ němu vlastní stanovisko a toto stanovisko obhájit. Jak bylo uvedeno výše, čeští žáci měli relativně větší problémy s delšími souvislými texty, menší problémy jim činila práce s grafy, tabulkami, náčrty či seznamy. Opakovaně se ukazuje, že největší obtíže činí českým žákům vyhledávat $v$ textu informace a samostatně argumentovat (Straková a Tomášek 1995; Straková a kol. 2002).

V oblasti matematického a prírodovědného učiva se výsledky českých žáků poněkud lišily podle typu úloh. Žáci dosahovali relativně horších výsledků v úlohách, kde museli své vědomosti uplatnit v nových neobvyklých situacích, a zejména v úlohách, které měly experimentální povahu. Ve výzkumu TIMSS 1995, který obsahoval experimentální složku, byla Česká republika zemí s největším rozdílem mezi výsledky žáků v teoretické a v experimentální části testu (Palečková a Mandíková 1997). Dobré znalosti žáků $v$ prírodovědných předmětech a zároveň menší dovednosti samostatně pracovat a uvažovat potvrdily rovněž výsledky výzkumu PISA 2006. Zde se čeští žáci vyznačovali výbornými výsledky v jednotlivých př́rodovědných disciplínách, daleko horší vědomosti vykazovali v oblasti principů prírodovědného bádání. Rovněž jim činilo potíže rozpoznat, jaké otázky lze zodpovědět př́rodovědným zkoumáním, a používat vědecké důkazy (Palečková a kol. 2007).

Poznatkům o silných a slabých stránkách přirodovědných vědomostí českých žáků odpovídají i mezinárodní komparace zamýšleného a realizovaného kurikula (TIMSS curriculum analysis, TIMSS 1999 Videostudy). Ty ukázaly, že výuka přírodovědných předmětů je v České republice na 2 . stupni základní školy pojmově náročná a poznatkově silně nahuštěná (Roth et al. 2006), přičemž učitelé za svůj primární cíl považují předávání poznatků. Žáci vykonávají málo praktických aktivit a kladou minimum otázek.

\subsection{POSTOJE}

Vedle vědomostí a dovedností zjištují mezinárodní výzkumy pravidelně také postoje žáků $\mathrm{k}$ jednotlivým vzdělávacím oblastem (předmětům) i ke škole obecně, plány ve vztahu k budoucímu studiu a podobně. Při interpretaci výsledků výzkumů $v$ českém prostředí bývá však těmto zjištěním věnována jen omezená pozornost. Mezinárodní výzkumy opakovaně poukázaly na negativní vztah českých žáků ke škole a k výuce ${ }^{17}$, přičemž národní analýzy ukázaly souvislost mezi vztahem ke škole a vzdělanostními aspiracemi ${ }^{18}$. Vývoj vztahu žákư ke škole a ke vzdělávání by se rozhodně měl stát předmětem dalšího zkoumání.

17 Informace o postojích českých žáků k jednotlivým předmětům Ize najít v závěrečných zprávách z výzkumů, které uvádíme v seznamu literatury.

18 O postojích českých žáků a jejich vzdělanostních aspiracích přinesl užitečné poznatky longitudinální výzkum PISA-L, který byl spuštěn spolu s šetřením PISA 2003. Dotazovaní žáci a jejich rodiče dostali doplňkové dotazníky a žáci byli sledováni až k přechodu na trh práce, respektive k vysokoškolskému studiu. Návratnost rodičovských dotazníkủ činila $75 \%$, dašího sledování se zůčastnilo 
Zajímavá zjištění přinesl i mezinárodní výzkum občanské výchovy, který poukázal na v mezinárodním srovnání vlažné občanské postoje českých žáků . Čeští žáci projevili podprůměrnou ochotu aktivně se pokoušet ovlivňovat život školy a v budoucnu se angažovat $v$ politických aktivitách. Přisuzovali rovněž malý význam občanským aktivitám a projevovali malou ochotu angažovat se $v$ humanitárních a charitativních činnostech (Kř́žová a kol. 2001).

\subsection{ROZLOŽENÍ VÝSLEDKU゚}

Mezinárodní výzkumy kromě toho, že poskytují informaci o výsledcích vzdělávání (vědomostech, dovednostech a postojích) a ukazují na určité souvislosti mezi výsledky a charakterem výuky, poskytují informaci o tom, jak jsou výsledky rozloženy $v$ rámci systému. Umožňují tak posoudit, jak funguje vzdělávací systém ve vztahu $\mathrm{k}$ dílčím skupinám žáků a zda nedochází ke znevýhodnění některých z nich.

Řada mezinárodních výzkumů poukázala na to, že v České republice existují velké rozdíly ve výsledcích žáků různých škol. Koeficient mezitřídní korelace, který udává, jaký podíl v rozdílech ve výsledcích Ize přiřadit rozdílu ve výsledcích žáků jednotlivých škol a jaký rozdílu ve výsledcích jednotlivých žáků v těchto školách, patří v ČR v mezinárodním srovnání tradičně k nejvyšším. V roce 2006 dosahovalo vyšší hodnoty pouze Německo, Mad'arsko a Nizozemsko. Tabulka 4 navíc ukazuje, že od roku 2000 dochází k jeho kontinuálním růstu, tedy rozdíly mezi jednotlivými školami se dále zvyšují. Tomu odpovídá i naše zjištění z kapitoly 2.1 , že se zvyšují rozdíly mezi jednotlivými typy škol (zatímco výsledky víceletých gymnázií zůstávají stabilní, výsledky základních škol se zhoršují). Ke zvyšování rozdílů dochází i ve výsledcích jednotlivých typů středních škol.

Tab. 4: Podíl rozdílu ( $\mathrm{v} \%)$ mezi jednotlivými školami na celkovém rozptylu výsledků

\begin{tabular}{llll}
\hline & 2000 & 2003 & 2006 \\
\hline čtenářská gramotnost & 43,5 & 43,2 & 59,1 \\
matematická gramotnost & 40,4 & 50,5 & 60,4 \\
př́rodovědná gramotnost & 36,0 & 40,8 & 57,8 \\
\hline
\end{tabular}

Zdroj: PISA (OECD 2007b)

ČR se vyznačuje nejen velkými rozdíly ve výsledcích jednotlivých škol, ale také silnou (a v čase neměnnou) souvislostí mezi výsledky žáků a jejich rodinným zázemím. Ve výzkumu PISA 2000 patřila Česká republika k zemím s nejvyšší závislostí výsledků žáků v testu čtenářské gramotnosti na jejich rodinném zázemí (OECD

$40 \%$ původních respondentů. Datové soubory z výzkumu PISA-L jsou součástí publikace Nerovné šance (Matějů, Straková 2006). Výzkum PISA-L ukázal souvislost mezi pozitivním vztahem žáků ke škole a jejich vzdělanostními aspiracemi. V souboru všech žáků narozených v roce 1987 byla hodnota korelačního koeficientu mezi indexem sounáležitosti žáka se školou a očekávaným vzděláním 0,16 (významná na hladině 0,01). Česká republika se řadí k zemím, kde je tento index výrazně pod mezinárodním průměrem. 
2001). Ve výzkumu PISA 2006 vykazovala ČR nejvyšší nárůst ve výsledku žáků v matematické a čtenářské gramotnosti s jednotkovým nárůstem v hodnotě indexu kulturního, sociálního a ekonomického statusu (OECD 2007).

\subsection{ROZŠíŘENÍ MEZINÁRODNÍCH VÝZKUMŮ NA NÁRODNÍ ÚROVNI}

Pro ČR představují mezinárodní výzkumy nejen možnost mezinárodního porovnání, ale jsou rovněž jediným zdrojem informací o výsledcích žáků v rámci celého vzdělávacího systému ${ }^{19}$. To je $v$ každém prípadě nevýhodné, nebot nemáme žádnou informaci o tom, jak se daři naplňovat národní vzdělávací cíle a rovněž některé další informace získáváme značně těžkopádně20.

Mezinárodní výzkumy poskytují informaci o výsledcích žáků jednotlivých typů studia. Vzorek je v ČR vybírán tak, aby na úrovni povinného vzdělávání byli reprezentativně zastoupeni žáci základních škol a víceletých gymnázií (přičemž u žáků základních škol je také zaznamenáváno, zda navštěvují výběrové třídy). Výzkum PISA zahrnuje do šetření žáky zvláštních, resp. praktických škol (z šetření IEA jsou tito žáci vyloučeni). Na úrovni ISCED 3 jsou vybírány reprezentativní vzorky všech oborů (gymnázia, maturitní a nematuritní studium). Data z mezinárodních výzkumů nám tak umožňují srovnávat výsledky žáků různých typů škol na úrovni 1. stupně ZŠ a na přelomu 2. stupně a středních škol. O rozdílech ve výsledcích na úrovni ZŠ jsme se zmínili v odstavci 2.1. Na úrovni ISCED 3 opakovaně pozorujeme velké rozdíly ve výsledcích žáků gymnázií, maturitních a nematuritních oborů. Dvě třetiny žáků nematuritních oborů opakovaně nedosahují takové úrovně čtenářské gramotnosti, která jim umožňuje řešit běžné čtenářské situace (např. Straková a kol. 2002).

Velkým informačním nedostatkem je absence poznatků o tom, jaké je rozložení výsledků u žáků, kteři opouštějí vyšší sekundární vzdělávání. Takové srovnání poskytl pouze výzkum matematického a př́rodovědného vzdělání TIMSS v roce 1995. Čeští žáci v něm dosáhli dobrých výsledků v 15 letech, v průběhu střední školy se však v žebříčcích výrazně propadli (Straková et al. 1998). Zároveň vykazovala ČR největší rozdíl ve výsledcích žáků všeobecných a odborných oborů. Následná šetření IEA již s populací osmnáctiletých nepracovala, nebot’ se ukázalo, že srovnání $v$ této věkové skupině je př́liš diskutabilní (i proto, že v řadě zemí se již značná část osmnáctiletých nachází mimo vzdělávací systém).

ČR provedla u žáků 3. ročníků středních škol výzkum PISA 2000, který však byl

19 Šetření maturant se týkají pouze maturitních oborů a dosud (s výjimkou roku 1998) neměla jednotnou administraci. Maturitní data ani data z testování žáků v 5. a 9. ročnících navíc nejsou volně k dispozici a jejich kvalita není dokumentována. Velkými datovými soubory obsahujícími informace o vědomostech a dovednostech žáků základních škol disponují společnost SCIO a projekt Kalibro, vzorky škol však nelze považovat za reprezentativní, nebot' šetření se účastní pouze ty školy, které o ně mají zájem. Datové soubory těchto společností nejsou také výzkumníkům volně dostupné a neobsahují dostatečně kvalitní informaci o rodinném zázemí žáků.

20 Například šetření krajů by bylo daleko jednodušší provést s využitím národního testu než při rozšiřování povinného vzorku patnáctiletých žáků ve výzkumu PISA (blíže se touto otázkou zabýváme níže). 
na mezinárodní úrovni určen pouze pro patnáctileté žáky, takže toto šetření neumožňuje mezinárodní srovnání a u žáků gymnázií již testy špatně rozlišují. Ve všech třech testovaných oblastech však výzkum prokázal obrovské nedostatky žáků nematuritního studia (Straková a kol. 2002), které by se bezpochyby projevily i při srovnání celé populace středoškoláků s jinými zeměmi.

Národním rozšiřením mezinárodních šetření byl již zmiňovaný výzkum PISA-L, který umožnil podrobněji mapovat přechod žáků ze základní na střední školu a ze střední školy na vysokou školu, prípadně na pracovní trh.

V rámci šetření PISA 2003 a 2006 dále proběhlo reprezentativní šetření žáků 9. ročníků (tedy byl rozšířen vzorek tak, aby byl nejen reprezentativní za populaci patnáctiletých, ale rovněž za populaci žáků 9. ročníku školní docházky).V rámci tohoto šetření proběhl rovněž pokus docílit také reprezentativity za kraje. Výběr vzorku při kombinaci národních a mezinárodních požadavků byl však natolik obtižný, že srovnání jednotlivých krajů se jeví být značně nespolehlivé21.

\section{VLIV MEZINÁRODNÍCH ŠETŘENÍ NA VZDĚLÁVACÍ POLITIKU V ČR}

\subsection{MEZINÁRODNÍ VÝZKUMY A KURIKULÁRNÍ REFORMA}

V roce 2008 organizovala OECD evaluaci výzkumu PISA. Rozliční aktéři v zúčastněných zemích odpovídali na otázky týkající se medializace výsledků výzkumu, jejich subjektivně vnímaného významu, dopadu na vzdělávací politiku. V ČR bylo dotazováno celkem 22 osob (4 akademici, 3 novinárii, 2 lokální politici, 3 rodiče, 6 tvưrců školské politiky, 4 ředitelé škol). Respondenti se shodovali v názoru, že výzkum PISA měl na vzdělávací politiku v ČR relativně malý dopad. Zjištění, že v ČR je PISA vnímána jako méně významný zdroj pro vzdělávací politiku, poskytlo i neformální2 ${ }^{22}$ srovnání výsledkủ evaluace $v$ jednotlivých zemích. Respondenti se shodovali $v$ tom, že data $z$ výzkumu PISA jsou v ČR nedostatečně využívána $k$ dalším analýzám, zmiňovali obecně nízkou podporu výzkumu a skutečnost, že rozhodnutí vzdělávací politiky v ČR nejsou zakládána na empirických zjištěních. Většina z nich se domnívala, že výzkum PISA podpořil do jisté míry kurikulární reformu a koncepční dokumenty s reformou spjaté a obrátil pozornost české pedagogické veřejnosti k významu čtenářské gramotnosti a nedostatkům českých žáků v této oblasti. Byl-li takto hodnocen výzkum PISA, nelze se domnívat, že by ostatním výzkumům mohla být přiřazována větší váha.

Česká kurikulární reforma i Národní program rozvoje vzdělávání v ČR (MŠMT

21 Kraje nevykazují konsistentní výsledky v čase ani přes jednotlivé oblasti. Vzhledem k nízkému počtu testovaných škol je výsledek kraje ovlivněn volbou konkrétní školy (např. výběr školy s rozšířenou výukou matematiky či informatiky v určitém kraji může národní srovnání značně zkreslit).

22 Analýza školních vzdělávacích programů ukazuje, že zatímco v maturitních oborech došlo k nárůstu objemu všeobecně vzdělávacích předmětů (ze $40 \%$ v r. 2004 na více než $50 \%$ v r. 2007), v nematuritních oborech zůstává beze změn (28 \%). (Kofroňová, Vojtěch 2008). 
2001), který je považován za ústřední dokument současné české vzdělávací politiky, byly bezesporu významně ovlivněny mezinárodními diskusemi o budoucnosti vzdělávání, které probíhaly na půdě $O E C D$ a jejichž produktem byl rovněž výzkum PISA. Z argumentací uvedených v českých koncepčních dokumentech vyplývá, že diskuse probíhající v mezinárodní komunitě byla pro jejich podobu podstatně významnější, než empiricky (nebo alespoň argumentačně) doložená potřeba národní. Je možno říci, že česká vzdělávací politika byla ovlivněna mezinárodními výzkumy na obecné koncepční úrovni, rozhodnutí vzdělávací politiky však nebyla motivována konkrétními nálezy výzkumů a nevyužila konkrétních podnětů, které mohly přispět $k$ úspěšné realizaci opatření. Výsledky a zejména metodologické a koncepční dokumenty výzkumu PISA i výzkumů IEA však nebyly využity pro argumentaci ani pro implementaci reformy. To je jistě škoda. Nálezy mezinárodních výzkumů obsahují pádné argumenty pro modifikaci tradičních vzdělávacích cílů a mohly pomoci získat širokou i odbornou veřejnost pro plánované změny. Výzkumy veřejného mínění (např. Straková, Basl, Veselý 2006) ukazují, že veřejnost potřebu změny necítí a velmi rozporuplné se $v$ tomto ohledu jeví i výpovědi učitelů a ředitelů škol (např. Kartouz 2006; ÚlV 2002-2008). Nedostatečné porozumění potřebnosti změn je pravděpodobně jednou ze závažných př́čin, které způsobují, že na mnoha školách je kurikulární reforma realizována pouze formálním způsobem (ÚlV 2002-2008). Potenciál mezinárodních výzkumů nebyl využit ani pro implementaci reformy. Koncepční dokumenty výzkumů obsahují podrobný popis vybraných kompetencí a jejich rozvoj do úrovní způsobilosti, znaky, podle kterých jsou úrovně definovány, návody pro hodnocení kompetencí, tedy řadu informací, které by pomohly pedagogické komunitě uchopit ty aspekty reformy, které jsou pro ni nové a obtížné.

\subsection{PŘíNOS MEZINÁRODNÍCH VÝZKUMU゚}

I když v konkrétních krocích vzdělávací politiky nepozorujeme bezprostřední vliv nálezů mezinárodních výzkumů, mezinárodní výzkumy bezesporu obrátily pozornost české odborné veřejnosti k některým specifickým problémům českého vzdělávacího systému. Prvním z těchto problémů je nízká úroveň čtenářské gramotnosti české žákovské populace. Poprvé na tento problém poukázal výzkum čtenářské gramotnosti v roce 1995 a každé další šetření v této oblasti tento nedostatek systému potvrdilo. Přesto nebylo prijiato žádné opatření, které by cílilo na posílení čtenářských kompetencí, které by vedlo $\mathrm{k}$ lepší príípravě učitelů v této oblasti, poskytlo jim metodické podklady, podpořilo rozvoj čtenářských dovedností v jiných předmětech, apod.

Druhý problém, na který upozornily mezinárodní výzkumy, je relativně silná závislost výsledků žáků na jejich rodinném zázemí, a velké rozdíly mezi výsledky žáků jednotlivých škol. Tento problém českého vzdělávacího systému je v odborné komunitě často diskutován a je obecně vnímán jako závažný. Ani zde však nebyly podniknuty žádné konkrétní kroky, které by aspirovaly na vyrovnávání vzdělávacích príležitostí nebo se alespoň pokusily zastavit zvětšování rozdílů. Nedošlo ani 
k tomu, že by u nově přijímaných opatření vzdělávací politiky bylo zkoumáno, zda nemají potenciál vzdělanostní nerovnosti dále zvyšovat.

Jak bylo zmíněno $v$ kapitole 2 , mezinárodní výzkumy se systematicky zabývají postoji žáků ke zkoumaným vzdělávacím oblastem, ke škole, ke vzdělávání. I když při prezentaci výsledků výzkumu TIMSS 1995 byla věnována velká pozornost skutečnosti, že čeští žáci vykazovali v mezinárodním srovnání velmi negativní vztah k matematice a fyzice, odborná komunita a vzdělávací politika věnují otázce motivace žáků stále minimální pozornost.

I když zjištění mezinárodních výzkumů nejsou vzdělávací politikou dostatečně využívána, mají přesto $v$ českém kontextu mimořádný význam $z$ toho důvodu, že predstavují prakticky jedinou informaci o výkonu českého vzdělávacího systému.

Jak již bylo zmíněno výše, $v$ českém vzdělávacím systému neprobíhá žádný systematický monitoring. Nejsou organizována žádná šetření, která by si kladla za cíl bud' zjistit, jak český vzdělávací systém naplňuje stanovené cíle vzdělávání (= do jaké míry žáci ovládají učivo závazně stanovené v kurikulárních dokumentech) nebo jak se liší výsledky pro dílčí skupiny žáků (žáky různých typů škol, různých obcí, žáky s různým ekonomickým či kulturním zázemím). První cíl není možno plně suplovat mezinárodními šetřeními, nebot' ta zjištují dosažení jiných cílů než těch, které jsou vymezeny v národních kurikulárních dokumentech. Mezinárodní výzkumy poskytují důležitou informaci o silných a slabých stránkách vzdělávacího systému v mezinárodním srovnání, ale neposkytují oporu pro diskuse o konkrétní podobě vzdělávacích cílů v celém českém kurikulu. Například při diskusích o př́lišném rozvolnění osnov a menším důrazu na faktické vědomosti reprezentované typicky historickými daty či spisovateli a výčty jejich děl se nemůžeme opř́it o žádnou znalost toho, do jaké míry žáci skutečně ovládali a ovládají předepsané učivo. Aby bylo možno vzdělávací politiku založit na dobré znalosti stavu, bylo by $v$ každém případě třeba doplnit informaci z mezinárodních šetření o národní monitoring.

Druhý cíl, tedy poskytnutí informace o fungování systému ve vztahu k různým skupinám populace plní mezinárodní šetření lépe. Průběžně přinášejí informace o výsledcích žáků z měst a vesnic, různých typů škol, informace o závislosti výsledků žáků na jejich rodinném zázemí. Nedostatečná byla dosud jejich schopnost informovat o dílčích výsledcích jednotlivých krajů či specifických znevýhodněných skupinách žáků (např. děti cizinců, romské děti a podobně). Již bylo zmíněno, že vzhledem k zaměěení na žáky $v$ povinné školní docházce neposkytují mezinárodní šetření dostatečnou informaci o rozdílech ve výstupních kompetencích žáků na výstupu ze střední školy. Tato informace je ovšem důležitá, nebot’ středoškolská docházka je v ČR téměř univerzální (odhadovaná míra předčasných odchodů ze vzdělávaní je $6 \%$ ) a dosavadní šetření svědčí o nízkých výstupních vědomostech žáků nematuritního studia. Tato skutečnost je tvůrci vzdělávací politiky dlouhodobě opomíjena. Nejsou přijímány žádné kroky k posílení obecných kompetencí žákư ${ }^{23}$ nematuritního studia a nedochází k monitoringu jejich vývoje.

23 Analýza školních vzdělávacích programů ukazuje, že zatímco v maturitních oborech došlo k nárůstu objemu všeobecně vzdělávacích předmětů (ze $40 \%$ v r. 2004 na více než 50 \% v r. 2007), v nematuritních oborech zůstává beze změn (28 \%). (Kofroňová, Vojtěch 2008). 
Mezinárodní šetření v oblasti výsledků vzdělávání obsahují řadu užitečných metodologických podnětů a poskytla velké bohatství informací. Tyto informace nebyly dosud dostatečně vytěženy výzkumníky a vzdělávací politika s nimi pracuje jen velmi omezeně. Aby se plně zhodnotily investice do těchto nákladných výzkumů, bylo by třeba existujících zdrojů systematičtěji využívat a doplnit je o pečlivě volené národní aktivity tak, aby společně poskytly komplexní informaci o fungování systému, na které by bylo možno budovat vzdělávací politiku založenou na empirických poznatcích (evidence based policy).

\section{LITERATURA}

Eurydice. Key competences: A developing concept in general compulsory education. Eurydice, 2002. (http://www.eurydice.org).

Hiebert, J.; R. Gallimore; H. Garnier et al. Teaching Mathematics in Seven Countries Results from the TIMSS 1999 Video Study. Washington: NCES, 2003.

Kartouz, B. Průzkum SCIO: Většina učitelů je proti reformě. Česká škola, 2006. http://www.ceskaskola.cz/Ceskaskola/Ar.asp?ARI=102826\&CAl=2124.

Kofroňová, O.; Vojtěch, J. Analýza školních vzdělávacích programů. 2007. (www. nuov.cz).

Kramplová, l.; Potužníková, E. Jak (se) učí číst. Praha: ÚlV, 2005.

Křižová, I. a kol. Znalosti, dovednosti a postoje čtrnáctiletých žáků v oblasti výchovy k občanství. Praha: ÚlV, 2001.

Matějů, P.; Straková, J. et al. (Ne)rovné šance na vzdělání. Praha: Academia, 2006.

OECD. Literacy in the Information Age. Final Report from the Adult Literacy Survey. Paris: OECD, 2000.

OECD. Knowledge and skills for life: First results from PISA 2000. Paris: OECD, 2001.

OECD. Learning for Tomorrow's World: First Results from PISA 2003. Paris: OECD, 2004.

OECD. Science Competencies for Tomorrow's World. First Results from PISA 2006. Paris: OECD, 2007.

Palečková, J.; Mandíková, D.. Tretí mezinárodní výzkum matematického a prírodovědného vzdělání. Výsledky českých žáků v praktických úlohách. Praha: VúP, 1997.

Palečková, J.; Tomášek, V. Posun ve znalostech čtrnáctiletých žákư v matematice a přirodních vědách. Zpráva o výsledcích mezinárodního výzkumu TIMSS. Praha: ÚlV, 2001.

Palečková, J. a kol. Hlavní zjištění výzkumu PISA 2006. Praha: ÚIV, 2007.

Procházková, I.; Raabová, E. Výchova k občanství a demokracii. Praha: ÚlV, 2002.

Roth, K. et al. Teaching Science in Five Countries: Results from the TIMSS 1999 Video Study. Washington: U.S. Department of Education, National Center for Education Statistics, 2006.

Rychen D.S.; Salganik L.H. (Eds.). Defining and Selecting Key Competencies. Göttingen: Hogrefe \& Huber Publishers, 2001.

Straková, J.; Tomášek, V. Mezinárodní studie čtenářské gramotnosti a její realizace v České republice. Praha: VúP, 1995.

Straková, J.; Tomášek, V.; Palečková, J. Mezinárodní výzkum matematického a př́ro- 
dovědného vzdělání. Souhrnné výsledky žáků 8. ročníku. Praha: VúP, 1996.

Straková, J.; Palečková, J.; Tomášek, V. Tretí mezinárodní výzkum matematického a př́rodovědného vzdělání. Souhrnné výsledky žáků 4. ročníků. Praha: VúP, 1997.

Straková, J.; Tomášek, V.; Palečková, J. Mezinárodní výzkum matematického a prírodovědného vzdělání. Souhrnné výsledky žáků posledních ročníků středních škol. Praha: VúP, 1998.

Straková, J. a kol. Vědomosti a dovednosti pro život. Čtenářská, matematická a prírodovědná gramotnost patnáctiletých žáků v zemích OECD. Praha: ÚlV, 2002.

Straková, J.; Basl, J.; Veselý, A. Základní a středni školství: po větší změně není poptávka. Tisková zpráva CVVM z dubna 2006 (www.cvvm.cas.cz).

Tomášek a kol. Výzkum TIMSS 2007. Obstojí čeští žáci v mezinárodní konkurenci? Praha: ÚlV, 2008.

ÚlV. Výsledky českých žáků v mezinárodních výzkumech 1995 - 2000. Praha: ÚlV, 2002. ÚlV 2002-2008. Rychlá šetření.(www.uiv.cz). 